\title{
Prospects of Angel Finance and Venture Capitalist Finance in Bangladesh
}

\author{
*Shabuz Mahmud \\ Lecturer, Department of Business Administration, World University of Bangladesh
}

\begin{abstract}
This study examines that the necessities of business angel investors and venture capitalists for the funding of start up businesses in our economy. Business Angel means an individual, acting alone or in a formal or informal group, who invests his or her own directly in an unquoted business and who after making the investment, takes an active involvement in the business, for example as an advisor or member of the board of directors. Angel investors, who are often wealthy individuals with experience building a business, provide early stage financing, called seed capital, for start-up ventures. Venture capitalists typically provide later stage financing, after the angels' investment. Many start-up businesses of Bangladesh need external financing to startup or growth stage of operations. If these new ventures anticipate quick and aggressive growth, they may turn to angel or venture capital investors for capital. Business Angels and VCs provide long term and committed share capital to help unquoted businesses grow and succeed. Angel and venture capitalist financing has provided seed capital for some famous U.S. businesses such as Bell Telephone, Ford Motor Company and Apple Computer. Entrepreneurial ventures dramatically affect Bangladesh economy and are the primary job creating engine of our economy. Where business has very limited access to funds and not bankable without security, the business angel and venture capitalist easily would ensure fund without security for highly potential business being a partner to make the business success.

Keywords: Venture Capitalist, Business Angel, Entrepreneur, Start-up Investment.
\end{abstract}

\section{Introduction:}

Business Angel means an individual, acting alone or in a formal or informal group, who invests his or her own directly in an unquoted business and who after making the investment, takes an active involvement in the business, for example as an advisor or member of the board of directors. Angel investors, who are often wealthy individuals with experience building a business, provide early stage financing, called seed capital, for start-up ventures. Venture capitalists (VCs) typically provide later stage financing, after the angels' investment. Most of the literature which addresses the start-up investment decision process has focused on how Business Angels and VCs make investment decisions. In fact, to the author's knowledge, this is the first empirical study addressing Prospects of Angel Finance and Venture Capitalist Finance in Bangladesh. It has been difficult to locate and survey angels (Mason \& Harrison, 2002). However, since the late 1990s, angels have started to form organizations in North America that help coordinate their efforts (Kauffman Foundation, 2002). Also, we can draw from the venture capital literature for angel investors due to some similarity of the investment process by angels and VCs. However, let us start with the differences between angel and VCs. An important difference in the process between how angels and VCs invest is that Angels perform less professional due diligence than VCs, invest more opportunistically, rely more on instincts, and do not calculate internal rates of return (Timmons,1990; Baty,1991; Mason \& Harrison,1996;Van Osnabrugge \& Robinson,2000). VCs may have a staff of people to perform due diligence or may hire professional firms to perform all or portions of the due diligence process (Van Osnabrugge \& Robinson, 2000). Since angel investors invest their own money (Benjamin \& Margulis, 2000), they are less accountable than VCs, and their lack of rigor can lead to poorer investment decisions. Angels and VCs also differ in their motives, their entrepreneurial experience, and their expected involvement (Van Osnabrugge \& Robinson, 2000). In general, angel investors are much more involved with the companies in which they invest than VCs, and are often involved more in day-to-day operations than VCs (Benjamin \& Margulis, 2000). In the U.S., 87 percent of Angels have operating experience (Freear and Wetzel, 1991), while a typical VC has little or no operating experience (Van Osnabrugge \& Robinson, 2000). Angels typically have more entrepreneurial experience than VCs; research has shown that 75 to 83 percent of angels have start-up experience as compared to approximately 33 percent for VCs (Van Osnabrugge \& Robinson, 2000). Often, angels will work part-time, with periods of full-time commitment, to help entrepreneurs through challenging issues (Van Osnabrugge \& Robinson, 2000). In fact, some angels are looking to work on a regular basis at their investments, whereas VCs rarely have the intention of being involved in operations (Benjamin \& Margulis, 2000). For these reasons, the angel investment often becomes more personal to both the investor and the entrepreneur. An angel investor is typically motivated beyond return on investment (ROI) (Benjamin \& Margulis, 2000; Van Osnabrugge \& Robinson, 2000), while VCs primary reason for existence is 
ROI. VCs are in business to return a profit on the partners' investment, while angels enjoy helping another entrepreneur build a business and giving back to the entrepreneurial community (Benjamin \& Margulis, 2000; Van Osnabrugge \& Robinson, 2000). In summary, VCs are more objective with regards to financial return, less emotionally attached, and more interested in ROI. The literature suggests that the entrepreneur is the most important factor when evaluating a start-up (MacMillan, Siegel, \& SubbaNarasimha, 1985, MacMillan, Zemann, \& SubbaNarasimha, 1987; Van Osnabrugge \& Robinson, 2000). Arthur Rock, a legendary venture capitalist, once said, "Nearly every mistake I've made has been in picking the wrong people, not the wrong idea" (Bygrave \& Timmons, 1992, p. 6). Both angels and VCs feel that the entrepreneur and the management team (Van Osnabrugge, 1998; MacMillan et al., 1987; Van Osnabrugge \& Robinson 2000) are the two factors that attract them to most deals. Macmillan, et al., (1985), for example, found that for VCs the quality of the entrepreneur ultimately determines the funding decision. Some literature suggests that angels are more attracted to the entrepreneur while VCs might be slightly more attracted to the idea (Van Osnabrugge \& Robinson, 2000).

\section{Objectives of the Study:}

1. To know about Angel Finance and VC Finance.

2. To explore the business seed Capital.

3. To evaluate the extent of VC Finance in Bangladesh.

4. To provide some directions about its' prospects in Bangladesh.

\section{Methodology:}

The study is empirical in nature. Mainly secondary data is used for data collection. The reason is that in our country the uses of Angel Finance and VC Finance are rare and most of the cases, the concepts are vague. To make this paper more informative different published textbooks, related articles, published research papers and newspapers have been analyzed. Literatures were generally collected from the said sources and the internet. As a result, a through review of literatures enabled us to make a consistent presentation of the theme of the study.

\section{Position of Business Angels and VCs in the financing stages:}

Private Equity comes in various forms and generally depends on the stage of development of the investee firm. Knowing the extent to which the business has matured is often an indication of the risks the business faces and the type of support it needs to get to the next stage. A classification is provided by the British Venture Capital Association. In their case investments in private companies are classified by the stage at which the funding is needed. Stage definitions are:

\begin{tabular}{|l|l|}
\hline Seed Stage & $\begin{array}{l}\text { Financing provided to research, assess and develop an initial concept before a business has reached a } \\
\text { start-up phase. }\end{array}$ \\
\hline Start-Up Stage & $\begin{array}{l}\text { Financing for product development and initial marketing. Companies may be in the process of being } \\
\text { set up or may have been in business for a short time, but have not sold their products commercially and } \\
\text { are yet to generate a profit. }\end{array}$ \\
\hline Expansion Stage & $\begin{array}{l}\text { Financing for growth and expansion of the company which is breaking even or trading profitably. } \\
\text { Capital may be used to finance increased production capacity, market or product development, and/or } \\
\text { to provide additional working capital. }\end{array}$ \\
\hline Replacement Capital & \begin{tabular}{l} 
Purchase of shares from another investor or to reduce gearing via the refinancing of debt. \\
\hline Buy out
\end{tabular} \\
$\begin{array}{l}\text { The acquisition of a significant portion, majority control or 100\% of businesses which normally entails } \\
\text { a change of ownership. Funds are often used for expansion, consolidations, turn-around, and spinouts } \\
\text { of divisions or subsidiaries. }\end{array}$
\end{tabular}

Table-1

Source: http://www.evca.com

There is only a limited number of Venture Capital funds focused on financing seed or start-up stages, although this is often the stage where Business Angels play a major role.

An emerging company which has constructed an experienced management team, a robust competitive position and strong gross margins usually has little need for Angel or VC investment. Early stage ventures with strong profit and high growth potential may be able to skip Angel financing and go direct to formal venture capital. The Angel plays the middle role: funding the business that has yet to stand on its own feet and not yet mature enough or with enough potential to attract venture capital. Angels typically invest in seed, start-up or early stage businesses.

Angels often play the financing role between 'family, friends and fools', often referred to as 'close money' and formal venture capital. Coping with what has come before and what comes after their involvement in the venture is a challenge for the Angel. On the one hand, Angels need to develop the business given the 
constraints inherited from earlier investors and then they need to prepare the business for the next round of investment, usually from formal venture capital. Even though the majority of their investee firms will not require venture capital, this will not always be apparent in the early stages of the Angel's involvement with the investee firm.

\section{Its' problem and prospects in the business sector in Bangladesh:}

The vulnerabilities of this sector have not yet been removed due to (i) financing constraints (ii) access to technology (iii) market linkage (iv) business support services etc. Angel financing and VCs financing could play a great role to serve the needs of business sector in Bangladesh. Then question may be raised- why and how?

\section{Why these will be essential?}

Equity financing in different stage of business as required

Dividend based or matching of repayment with harvest/sale i.e. with cash inflow

Shouldering business risk being partner

Nursing with technological support, market linkage and business support services

Use and source of Business Angel and Venture Capital in Business Development:

\begin{tabular}{|c|c|c|c|c|c|c|}
\hline $\begin{array}{l}\text { Stage } \\
\text { Cycle }\end{array}$ & R \& D & Startup & $\begin{array}{l}\text { Early } \\
\text { Growth }\end{array}$ & $\begin{array}{l}\text { Accelerating } \\
\text { Growth }\end{array}$ & $\begin{array}{l}\text { Sustaining } \\
\text { Growth }\end{array}$ & $\begin{array}{l}\text { Maturity } \\
\text { Growth }\end{array}$ \\
\hline $\begin{array}{l}\text { Type of } \\
\text { funding }\end{array}$ & $\begin{array}{l}\text { Proof of } \\
\text { Concept } \\
\text { Funding }\end{array}$ & Seed & $\begin{array}{l}\text { First } \\
\text { Round }\end{array}$ & $\begin{array}{l}\text { Second } \\
\text { Round }\end{array}$ & $\begin{array}{l}\text { Development } \\
\text { Capital }\end{array}$ & $\begin{array}{l}\text { Replacement } \\
\text { Capital }\end{array}$ \\
\hline \multirow{5}{*}{$\begin{array}{l}\text { Sources } \\
\text { of } \\
\text { funding }\end{array}$} & \multicolumn{2}{|c|}{ Private Sector } & & & & \\
\hline & \multicolumn{3}{|c|}{ Founders, family and friends } & & & \\
\hline & \multirow{2}{*}{\multicolumn{4}{|c|}{ Business Angels }} & & \\
\hline & \multirow{2}{*}{\multicolumn{5}{|c|}{ Venture Capital }} & \\
\hline & & & & & & \\
\hline
\end{tabular}

Table-2

The table indicates the roles of Business Angels and VCs for an organization from start up to maturity growth where as other sources of financing are limited to some extent.

\section{How these will serve the economy?}

Business Angels and VCs provide long term and committed share capital to help unquoted companies grow and succeed. Both could help when entrepreneur(s) is looking to:

$\square$ Start up

$\square$ Growth and expansion

Buy into a business

Buyout a division of a parent company

Turnaround or revitalize a company

As stated earlier, all of the above funders (not included Angels and VCs) have some limitations and traditional operational style to finance for expansion of business. Venture capitalist is a shareholder/partner of entrepreneurs committed to finance in different stage of business for the emerging potential business and its continuous expansion and growth.

The characteristic of VCs is to be partner of entrepreneur of early-stage, high-potential, and growth companies to trickledown benefit as shareholders primarily and finally in the interest of generating a return through an eventual realization event such as an IPO and trade sale of the company exercising call or put option.

Structure-Product and Services: We have some limitations to introduce typical angel and venture capital products in Bangladesh for the following reasons:

$\square$ Most of the business are proprietorship or partnership not a company registered with RJSCF and sponsors' non-willingness to register primarily

$\square$ No credibility of operational systems \& financial statements of the business either registered or not

The partners or shareholders of the business registering good profit are not interested to accept the financer as shareholders and to include anybody as owner outside family or friends.

$\square$ Not well compliant of applicable laws regulations; and has tax evasion and profit hiding tendency resulting of a threat of bad equity investment both investor and social aspect. 
Considering the above limitations, the product should be designed protecting both downside and upside and preferably quasi equity something like mezzanine financing (a hybrid of debt and equity financing) for both non registered \& registered business and redeemable or redeemable convertible preference shares in addition to ordinary shares for registered companies may be suitable product for Bangladesh from investor perspective.

When entrepreneurs approach venture capitalists for funding, they perform due diligence process through analyzing the business plan including financial projection for several years generally for five years and conducting independent research to determine the viability and potential of the plan. The Venture capitalist should have target to choose the high potential business through efficient due diligence to make it larger by financing phase by phase professionally with a view to making empowered to go to banks and FIs and into capital market through IPO and finally harvest the best return through trade sale of the company exercising call or put option as stated earlier.

\section{The angels and venture capitalists may provide the following services to investees:}

Capacity Building Services: Training for specialization on operation, accounting, tax, VAT and other operational issues.

Marketing Support Services: Market linkage nationally and internationally and product development.

Marketing strategy and Distribution Networks: To determine marketing strategy and set up distribution networks for optimum performance with a synergy effect.

The angel and venture capitalist may charge management fees or technical know how fees for the above services with the rate of growth after financing and providing services. Whatever the product is, generally angel or venture capitalist does the following process (i) obtaining business plan (ii) conducting due diligence (iii) providing term sheet (iv)executing shareholders' agreement/investment agreement, (v) Investment (vi) Support services, if required (Vii) Financing by round or phase (Vii) Exit.

The Market/Target Customer: The target customer of angel and venture capitalist in Bangladesh should be the following businesses who add value in product and services (not trader/commercial importer or exporter):

\section{Proprietorship}

Partnership

Registered unlisted companies private or public

Either angel or venture capitalist in Bangladesh should prefer to invest on thrust sector as defined in Industrial Policy 2010 including agricultures, agro based industry and agro-processing industry.

Pros and Cons of Investees: The investees may obtain the services like Business Consultation, Management Consultation, Human Resources, and Additional Resources like payroll, tax and other legal matter may be considered pros and the investees may surprise for the requirement of venture capitalists like Management Position, Equity Position, Decision Making, Business Plan and Funding Plan as guided by it which may be considered cons. However, in perspective of financing as partner with collateral and its success phase by phase, venture capital is definitely an angel for investees to emerge and grow continuingly.

Funder: Generally angels and venture capitalists are own funded. The entrepreneurs may come up with an idea having market demand but short of money. On the other hands, individuals having a lot of money may have short or no ideas. So the above two parties may come together in the format of seed capital. Thus, the angel and venture capital comes from high net worth individuals in institutional forms or corporate entities that use funds from other investors - sometimes large institutions--and manage that money by investing it in growth businesses. In addition to paid up capital of sponsors of angels or venture capitalists, the development fund may be attracted from different development agencies/banks like IFC, ADB, JICA, NORAD, CIDA, USAID, USDA, Acumen Fund etc. either as term loan or in any form with a very minimum rate of interest or no interest. However, considering the high risks involving with businesses, the angels or venture capitalists need own capital or cheaper fund or a development fund having no interest to invest in businesses and credit lines from banks and financial institutions will not be a good source of fund because of higher rate of interest.

Competitor: No strong competitor is still working covering all areas and sectors of business in Bangladesh and those who are working on serving financially on business have limited access either legally or technically or strategically. Hence, Banks, FIS and MFIs cannot serve business efficiently as the way they need to survive, emerge and expand continuingly. Being angels are undefined in our country so, there is no competitor of angels. At present two/three venture capitalists started operation in a very limited scale and some others may involve in processing to incorporate. In order to serve more than 6.00 million SMEs in all over the countries, such two or three venture capitalists is really very few to address their need and in addition to that, emerging of more angels 
and venture capitalists would ensure competitive sound practice of angel and venture capital financing in Bangladesh ensuring legal, financial and tax back up from the government.

Risk Management: Angel or Venture Capital sometimes is described as legalized gambling and a career in angel or venture capital requires strong business sense. As an investor, a business angel or venture capitalist is approached by entrepreneurs and small companies needing money to help their ideas become successful businesses. In the event the company does succeed, the business angel and venture capitalist will see the initial money back as well as interest or a percentage of any future profits. However, sometimes a business fails, and the angel and venture capitalist is left with a loss. Thus, the risks associated with angel finance and VCs finance the individuals or firms are often off-set by the successful few investments that drive profits. Fred Wilson, a well-known venture capitalist, argues that VCs should expect a third of their ventures to fail, a third to under perform, and the remaining third to generate between a fivefold and tenfold return. However, to trickled own the more benefit from investment, the business angels and VCs have to keep the risk within tolerable and acceptable range through effective monitoring of the investees' business and providing business support services to minimize the avoidable risk of investment. Different venture capital firms have different appetites for the risks market risk, technical risk, operational risk and financial risk associated with the investment. Venture capitalist may hold a very diverse investment portfolio to limit the impact of failing ventures and poor business climates.

Success History of Venture Capitalists in the World: Google, Face book, twitter, Amazon, Intel, Apple, Fedex, Genetech, Bloom Energy, Yahoo, Pay Pall, Tesla Motors, Hotmail, and Skype etc. are some success venture backed companies which born and grew in the hands of venture capitalists. Some of such success venture capitalists are Andreessen Horowitz, Union Square Venture Partners, General Catalyst Partners, Khosla Ventures, First Round Capital, Spark Capital, Draper Associates, Kleiner Perkins Caufield \& Byers, and Sequoia.

Capital that played a great role to emerge most famous venture-backed companies. Venture capital financing not only ensure to growth of business but also ensure a lot of multiplier effect on national economy favorably including employment generation. Every year, there are nearly 2 million businesses created in the USA. According to the National Venture Capital Association, $11 \%$ of private sector jobs come from venture backed companies and venture backed revenue accounts for $21 \%$ of US GDP.

Legal and Formal Back up: As per section 2(b)(iv) of the Financial Institutions Act, 1993, venture capitalists will be a financial institutions and the government has to frame effective regulations under that act to operate and guide them in line with existing business scenario, practices of the existing venture capitalists in Bangladesh and the standard international practices of venture capital.

The registered venture capitalist i, e the Company with Registrar of Joint Stock of Companies and Firms (RJSCF) can operate having a No Objection Certificate (NOC) which restricts the banking business under section 4(b) of the Bank Companies Act, 1991. But the venture capitalist would be legally able to conduct 'financing business' under section 2(a) of the said Financial Institutions Act, 1993 being a financial institution. However, the following legal and formal back up are urgently required to emerge venture capitalist in Bangladesh with a view to promoting \& setting up vibrant business:

(i) The Government should specially emphasize the road map of business with Venture Capital financing in Industrial Policy.

(ii) Tax exemption from income of venture capitalists for promoting business essentially required for development of national economy.

(iii) Right to legal action in any court in as downside protection for quasi equity or mezzanine financing other than legal action under Negotiable Instrument Act and Criminal Procedure Code.

(iv) Introducing insurance coverage on invested amount to avoid the risk of money lost due to natural calamity, if feasible, in addition to existing insurance facility.

(v) Provide cheaper fund from Government or manage by the Government for Venture capitalists.

Wrapping up: Where business has very limited access to funds and not bankable without security, the business angel and venture capitalist easily would ensure fund without security for highly potential business being a partner to make the business success one and definitely, we must take care of this angels for the sake of industrialization. 


\section{References:}

[1]. Baty, G.B. (1991). Entrepreneurship for the 1990s. Englewood Cliffs, NJ: Prentice Hall.

[2]. Benjamin, G.A. \& Margulis, J. (2000). Angel Financing: How to Find and Invest in Private Equity. New York: John Wiley \& Sons.

[3]. Bygrave, W.D. \& Timmons, J.A. (1992). Venture Capital at the Crossroads. Boston, MA: Harvard Business School Press.

[4]. Freear, J. \& Wetzel, W.E. (1991, April). The informal venture capital market in the year 2000. Paper presented at the Third Annual International Research Symposium on Small Business Research, Florida State University.

[5]. Kauffman Foundation. (2002). Business angel investing groups growing in North America. Retrieved April 10, 2013, from http://www.kauffman.org/pdf/angel_summit_report.pdf.

[6]. MacMillan, I.C., Sigel, R., \& SubbaNarashimha, P.N. (1985). Criteria used by venture capitalists to evaluate new venture proposals. Journal of Business Venturing, 1, 119-128.

[7]. MacMillan, I.C., Zemann, L., \& SubbaNarashimha, P.N. (1987). Criteria distinguishing successful from unsuccessful ventures in the venture screening process. Journal of Business Venturing, 2, 123-137.

[8]. Mason, C.M. \& Harrison, R.T. (1996). Why 'business angels' say no: a case study of opportunities rejected by an informal investor syndicate. International Small Business Journal, 14(2), 35-51.

[9]. Mason, C.M. \& Harrison, R.T. (2002). Is it worth it? The rates of return from informal venture capital investments. Journal of Business Venturing, 17, 211-236.

[10]. Roy, Dipok Kumar. (2012). Venture Capital for SMEs in Bangladesh- the Angel we Need!. The Bangladesh Accountant quarterly Journal of the institute of Chartered accountant of Bangladesh July-September 2012.

[11]. Timmons, J.A. (1990). Planning and Financing the New Venture. Acton, MA: Brick House Publishing Co.

[12]. Van Osnabrugge, M. (1998). The Financing of Entrepreneurial Firms in the UK. Unpublished doctoral dissertation, University of Oxford.

[13]. Van Osnabrugge, M. \& Robinson, R. J. (2000). Angel investing: matching start-up funds with start-up companies: the guide for entrepreneurs, individual investors, and venture capitalist. San Francisco:Jossey-Bass. 